\title{
Synthesis of $\mathrm{Al}_{3} \mathrm{BC}_{3}$ particulates by carbo-thermal reduction process-Parameter optimization and mechanism analysis
}

\author{
Sea-Hoon LEE, ${ }^{\dagger}$ Jie YIN, Lun FENG and Jin Seok LEE ${ }^{*}$ \\ Korea Institute of Materials Science, 797 Changwondaero, Changwon, Gyeongnam, 641-831, Republic of Korea \\ *Korea institute of Energy Research, 102 Gajeongro, Yuseonggu, Deajeon, 305-343, Republic of Korea
}

\begin{abstract}
The synthesis mechanism of $\mathrm{Al}_{3} \mathrm{BC}_{3}$ through carbo-thermal reduction process was investigated and the processing conditions were optimized using $\mathrm{Al}(\mathrm{OH})_{3}-\mathrm{B}_{2} \mathrm{O}_{3}-\mathrm{C}$ as starting materials. The mass change and phase formation of the compacts were analyzed with varying temperature. Excess $\mathrm{Al}(\mathrm{OH})_{3}$ and $\mathrm{B}_{2} \mathrm{O}_{3}$ were required compared to the stoichiometric composition due to the loss of the source materials by vaporization at $1,500-1,600^{\circ} \mathrm{C}$. At $1,600^{\circ} \mathrm{C}, \mathrm{Al}_{2} \mathrm{O}$ gas began to actively react with carbon to form $\mathrm{Al}_{4} \mathrm{C}_{3}$ on the carbon particles. $\mathrm{Al}, \mathrm{Al}_{2} \mathrm{O}$ and $\mathrm{B}_{2} \mathrm{O}_{3}$ gases diffused through $\mathrm{Al}_{4} \mathrm{C}_{3}$ layer and reacted with carbon at and above $1,650^{\circ} \mathrm{C}$ to form $\mathrm{Al}_{3} \mathrm{BC}_{3}$. The formation of hexagonal terrace at the surface of synthesized powder indicated that the gases also reacted at the particle surface with carbon which diffused through the carbide layers. The reactions were completed after calcination at $1,725^{\circ} \mathrm{C}$ for $4 \mathrm{~h}$ or at $1,800^{\circ} \mathrm{C}$ for $1 \mathrm{~h}$. Gas-solid reactions were the major synthesis mechanism. The optimum composition for the synthesis of the ternary compound was $\mathrm{Al}(\mathrm{OH})_{3}: \mathrm{B}_{2} \mathrm{O}_{3}$ :carbon $=0.7: 1.4: 0.25$ by weight.
\end{abstract}

(2014 The Ceramic Society of Japan. All rights reserved.

Key-words : Carbo-thermal reaction, $\mathrm{Al}_{3} \mathrm{BC}_{3}$, Powder, Synthesis, $\mathrm{SiC}$

[Received February 24, 2014; Accepted June 20, 2014]

\section{Introduction}

Silicon carbide $(\mathrm{SiC})$ is one of the important ceramics for structural application because it has unique combination of beneficial properties such as high hardness, strength, chemical stability, thermal conductivity and excellent thermal stability. ${ }^{1)}$

Preparation of highly concentrated SiC slurry and subsequent low temperature pressureless sintering of the resultant green body have been challenging topics during the last decade for the production of $\mathrm{SiC}$ components. However, $\mathrm{SiC}$ green bodies prepared by wet processing generally required very high temperatures $\left(2,000-2,250^{\circ} \mathrm{C}\right)$ for densification. ${ }^{2-4)}$

Recently, $\mathrm{Al}_{3} \mathrm{BC}_{3}$ has been used as a sintering additive of $\mathrm{SiC}$ due to the high sintering efficiency and flexibility for wet processing. ${ }^{5)}$ Highly concentrated $\mathrm{SiC}$ slurry containing $\mathrm{Al}_{3} \mathrm{BC}_{3}$ additive could be casted and densified either by pressureless sintering at $1,850^{\circ} \mathrm{C}$ or spark plasma sintering (SPS) at $1,550^{\circ} \mathrm{C}^{5)-7)}$ The additive has potential application for $\mathrm{SiC}$ components having complex shapes such as $\mathrm{SiC}$ tubes and $\mathrm{SiC} /$ $\mathrm{SiC}$ fiber-reinforced composites.

Various efforts have been reported for the synthesis and analysis of $\mathrm{Al}_{3} \mathrm{BC}_{3}$ by using the mixture of $\mathrm{Al}, \mathrm{B}$ (or $\mathrm{B}_{4} \mathrm{C}$ ) and $\mathrm{C}$ as starting materials. ${ }^{8)-16)}$ Hillerbrecht et al. synthesized $\mathrm{Al}_{3} \mathrm{BC}_{3}$ as small single crystals in an aluminum melt. ${ }^{8)}$ Lee et al. reported that the dissolution of $\mathrm{B}_{4} \mathrm{C}$ and $\mathrm{C}$ within $\mathrm{Al}$ melt and subsequent precipitation of $\mathrm{Al}_{3} \mathrm{BC}_{3}$ were the major synthesis mechanisms. ${ }^{15)} \mathrm{Li}$ et al. reported the synthesis of bulk $\mathrm{Al}_{3} \mathrm{BC}_{3}$ by reactive hot pressing and proposed the synthesis mechanism as solid-solid reactions. ${ }^{14)}$

Metal carbides have been prepared by the carbo-thermal reduction of metal oxides, direct reaction between metal elements and carbon, and the gas phase reaction of metal-containing gases and appropriate hydrocarbons. ${ }^{17)}$ Among the processes, carbo-thermal reduction of metal oxides is the most commonly used route for industrial production due to inexpensive raw

\footnotetext{
Corresponding author: S.-H. Lee; E-mail: Seahoon1@kims.re.kr
}

materials and simple process. However, in spite of the importance of the process, the synthesis of ternary carbides using carbothermal reduction process has been scarcely investigated. ${ }^{18), 19)}$ Especially, the synthesis of $\mathrm{Al}_{3} \mathrm{BC}_{3}$ by the process has never been reported.

The present investigation reports the synthesis of $\mathrm{Al}_{3} \mathrm{BC}_{3}$ powder using the mixtures of $\mathrm{Al}(\mathrm{OH})_{3}, \mathrm{~B}_{2} \mathrm{O}_{3}$, and phenolic resin through carbo-thermal reduction process. $\mathrm{Al}(\mathrm{OH})_{3}$ was selected in order to reduce the price and to increase the activity of the raw powder. Phenolic resin induced homogeneous distribution of carbon source because of the high solubility in ethanol. Processing parameters such as calcination condition and the mixing ratio of the raw powders were optimized and the synthesis mechanism of the ternary carbide was established.

\section{Experimental procedures}

Aluminum hydroxide $\left[\mathrm{Al}(\mathrm{OH})_{3}, 99.99 \%, 2.5 \mu \mathrm{m}\right.$, Kojundo Chemical Lab. Co., Japan], boron oxide $\left(\mathrm{B}_{2} \mathrm{O}_{3}, 99.9 \%, 3 \mu \mathrm{m}\right.$, Kojundo Chemical Lab. Co., Japan), and phenolic resin (J-325, Dainippon Ink and Chemicals Inc., Japan, carbon yield: 25\%) were used as the source materials of $\mathrm{Al}, \mathrm{B}$, and $\mathrm{C}$, respectively. The carbon yield of the resin was measured by TG-DTA in a former experiment. ${ }^{15}$ ) The molar ratio of the starting materials was varied as shown in Table 1.

The starting powders $(10 \mathrm{~g})$ were mixed using a ball mill with $\mathrm{SiC}$ ball $(200 \mathrm{~g}$, diameter: $10 \mathrm{~mm})$, polyethylene bottle $(500 \mathrm{ml})$ and ethanol for $24 \mathrm{~h}$. Then, the slurries were dried with stirring using a hot plate. Thermo-gravimetric analysis (TGA, STA 409PC, Netzshch Geraetebau Inc., Germany) of the powder mixture was performed up to $1,950^{\circ} \mathrm{C}$ in flowing Ar atmosphere (flow rate: $20 \mathrm{ml} / \mathrm{min}$, heating rate: $5^{\circ} \mathrm{C} / \mathrm{min}$ ). The powder mixtures were heated using a tube furnace at $1,000^{\circ} \mathrm{C}$ for $30 \mathrm{~min}$ in flowing Ar to change phenolic resin into carbon. After crushing using a mortar and sieving through a 100 mesh sieve, the powder mixtures were compacted into $\phi 13 \times 13 \mathrm{~mm}$ pellets using a hand press under $1 \mathrm{MPa}$ pressure. The pellets were placed in a graphite 
Table 1. Chemical composition (wt \%) of starting materials and secondary phases formed after calcination at $1,800^{\circ} \mathrm{C}$ for $1 \mathrm{~h}$

\begin{tabular}{cclcc}
\hline Abbreviation & $\mathrm{Al}(\mathrm{OH})_{3}$ & $\mathrm{~B}_{2} \mathrm{O}_{3}$ & $\begin{array}{c}\text { Phenolic } \\
\text { resin }\end{array}$ & $\begin{array}{c}\text { Secondary } \\
\text { phases }\end{array}$ \\
\hline $\mathrm{AC}$ & 0.7 & 0 & 0.9 & $\mathrm{Al}_{4} \mathrm{C}_{3}$ \\
$\mathrm{ABC} 1$ & 0.7 & 1.3 & 0.9 & $\mathrm{Al}_{4} \mathrm{C}_{3}, \mathrm{Al}_{2} \mathrm{O}_{3}$ \\
$\mathrm{ABC} 2$ & 0.7 & 1.35 & 0.95 & $\mathrm{Al}_{4} \mathrm{C}_{3}$ \\
$\mathrm{ABC} 3$ & 0.7 & 1.4 & 1 & - \\
$\mathrm{ABC} 4$ & 0.7 & 1.5 & 1 & - \\
$\mathrm{ABC5}$ & 0.7 & 1.5 & 1.2 & Carbon \\
$\mathrm{ABC6}$ & 0.7 & 1.7 & 1 & - \\
\hline
\end{tabular}

crucible and were heated at $1,550-1,800^{\circ} \mathrm{C}$ for $0.5-4 \mathrm{~h}$ in flowing Ar using an induction furnace (FVHP-1-3, Fuji Denpa Kogyo Corp., heating rate: $75^{\circ} \mathrm{C} / \mathrm{min}$ up to $1,500^{\circ} \mathrm{C}, 30^{\circ} \mathrm{C} / \mathrm{min}$ above $1,500^{\circ} \mathrm{C}$ ). For comparison, $\mathrm{Al}-\mathrm{B}_{4} \mathrm{C}-\mathrm{C}$ powder mixture was also used for the synthesis of $\mathrm{Al}_{3} \mathrm{BC}_{3}$. Details on the synthesis process using $\mathrm{Al}-\mathrm{B}_{4} \mathrm{C}-\mathrm{C}$ source were described elsewhere. ${ }^{15)}$ The phase identification of synthesized powders was performed by X-ray diffractometry (XRD, RINT-UltimaIII, Rigaku Co., Japan) using $\mathrm{CuK} \alpha_{1}$ radiation. The morphology of the synthesized $\mathrm{Al}_{3} \mathrm{BC}_{3}$ powder was observed by scanning electron microscopy (SEM, JSM-6700F, JEOL Ltd., Japan).

Aluminum, boron, carbon and oxygen content of the compound powder was measured using an inductively-coupled plasma atomic emission spectrometry (analyzed components: aluminum and boron, ICP-AES, Optima 3300DV, Perkin Elmer, Wellesley, MA), infrared absorption method (analyzed component: carbon, CS 444-LS, Leco, St. Joseph, MI) and inert gas carrying melting-infrared absorption method (analyzed component: oxygen, TC-600, Leco), respectively.

\section{Results and discussion}

\subsection{Optimization of starting composition}

The reactions to form $\mathrm{Al}_{3} \mathrm{BC}_{3}$ using $\mathrm{Al}(\mathrm{OH})_{3}, \mathrm{~B}_{2} \mathrm{O}_{3}$ and $\mathrm{C}$ can be described as follows;

$$
\begin{aligned}
& 2 \mathrm{Al}(\mathrm{OH})_{3(\mathrm{~s})} \rightarrow \mathrm{Al}_{2} \mathrm{O}_{3(\mathrm{~s})}+2 \mathrm{H}_{2} \mathrm{O}_{(\mathrm{g})}, \\
& 3 \mathrm{Al}_{2} \mathrm{O}_{3(\mathrm{~s})}+\mathrm{B}_{2} \mathrm{O}_{3(\mathrm{~s})}+18 \mathrm{C}_{(\mathrm{s})} \\
& \quad \rightarrow 2 \mathrm{Al}_{3} \mathrm{BC}_{3(\mathrm{~s})}+12 \mathrm{CO}_{(\mathrm{g})} .
\end{aligned}
$$

The standard Gibbs free energy of reaction (2) could not be obtained due to the lack of the thermodynamic data of $\mathrm{Al}_{3} \mathrm{BC}_{3}$.

According to reactions (1) and (2), the theoretical molar ratio of the constituents to form $\mathrm{Al}_{3} \mathrm{BC}_{3}$ is $\mathrm{Al}(\mathrm{OH})_{3}: \mathrm{B}_{2} \mathrm{O}_{3}: \mathrm{C}=3: 0.5: 9$. Because $\mathrm{Al}(\mathrm{OH})_{3}$ and phenolic resin lose weight to form $\mathrm{Al}_{2} \mathrm{O}_{3}$ and carbon during heating, the theoretical mass ratio of $\mathrm{Al}(\mathrm{OH})_{3}$ : $\mathrm{B}_{2} \mathrm{O}_{3}$ :phenolic resin based on reaction (2) is 0.7:0.104:1.293.

Table 1 listed the secondary phases which formed after synthesis with changing the mixing ratio of the raw materials. The optimum composition was $\mathrm{Al}(\mathrm{OH})_{3}: \mathrm{B}_{2} \mathrm{O}_{3}$ :phenolic resin (carbon) $=0.7: 1.4: 1(0.25)$ by weight (composition $\mathrm{ABC} 3) . \mathrm{Al}_{4} \mathrm{C}_{3}$ was formed when the mass ratio of $\mathrm{Al}(\mathrm{OH})_{3} / \mathrm{B}_{2} \mathrm{O}_{3}$ was more than 0.5 because of the depletion of $\mathrm{B}_{2} \mathrm{O}_{3}(\mathrm{ABC} 1, \mathrm{ABC} 2)$. When excess $\mathrm{B}_{2} \mathrm{O}_{3}$ was added, residual $\mathrm{B}_{2} \mathrm{O}_{3}$ phase or secondary boride phase formation was not detected by $\mathrm{X}$-ray analysis due to the formation of amorphous $\mathrm{B}_{2} \mathrm{O}_{3}$ and the vaporization of remaining $\mathrm{B}_{2} \mathrm{O}_{3}(\mathrm{ABC} 4-\mathrm{ABC} 6)^{20)}$

\subsection{Synthesis mechanism}

Reaction (2) is a simplified solid-solid reaction formula. However, the actual synthesis of $\mathrm{Al}_{3} \mathrm{BC}_{3}$ was performed by various reactions between solids, liquids and gases.

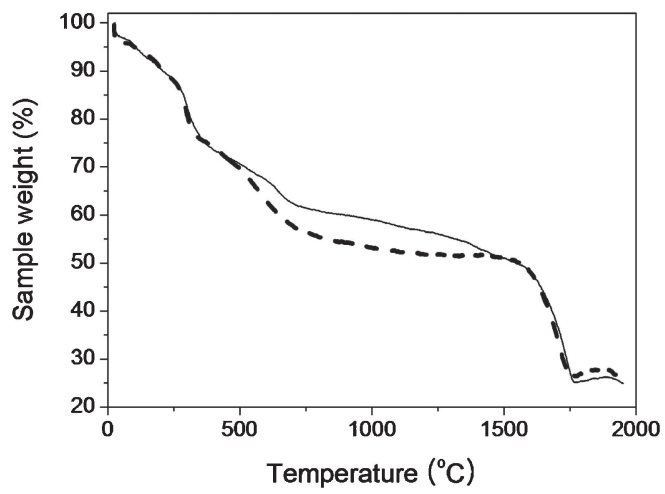

Fig. 1. TGA data of the raw powder mixtures. (...: $\mathrm{AC},-$ : $\mathrm{ABC} 3)$

Figure 1 shows the TGA data of raw powder mixtures. The dehydration of $\mathrm{Al}(\mathrm{OH})_{3}$ occurred at $250-300^{\circ} \mathrm{C}$. The decomposition of the phenolic resin during pyrolysis mostly occurred below $1,000^{\circ} \mathrm{C}$. The mass loss of the $\mathrm{AC}$ and $\mathrm{ABC} 3$ was similar below $1,050^{\circ} \mathrm{C}$ except the magnitude. The $\mathrm{ABC} 3$ had less weight loss than the $\mathrm{AC}$ below $1,050^{\circ} \mathrm{C}$ because the $\mathrm{ABC} 3$ contained $\mathrm{B}_{2} \mathrm{O}_{3}$ which is thermally stable up to $1,000^{\circ} \mathrm{C}$ while both $\mathrm{Al}(\mathrm{OH})_{3}$ and the resin lost weight in the AC. The difference of mass loss between the $\mathrm{AC}$ and $\mathrm{ABC} 3$ decreased above $1,050^{\circ} \mathrm{C}$ because $\mathrm{B}_{2} \mathrm{O}_{3}$ in the $\mathrm{ABC} 3$ began to vaporize. ${ }^{21)}$

Both the $\mathrm{AC}$ and $\mathrm{ABC} 3$ showed strong mass loss above $1,500^{\circ} \mathrm{C}$ due to the decomposition of $\mathrm{Al}_{2} \mathrm{O}_{3}{ }^{22)-24)}$

$$
\mathrm{Al}_{2} \mathrm{O}_{3(\mathrm{~s})}+2 \mathrm{C}_{(\mathrm{s})} \rightarrow \mathrm{Al}_{2} \mathrm{O}_{(\mathrm{g})}+2 \mathrm{CO}_{(\mathrm{g})}
$$

Because reaction (2) accompanies weight loss which was originated from the formation of $\mathrm{CO}$ gas, TGA data indicated that the formation of $\mathrm{Al}_{3} \mathrm{BC}_{3}$ does not actively occur below $1,500^{\circ} \mathrm{C}$. Mass loss mostly finished at $1,750^{\circ} \mathrm{C}$.

Figure 2 shows the $\mathrm{XRD}$ data of the $\mathrm{ABC} 3$ after heating up to $1,800^{\circ} \mathrm{C}$ for $30 \mathrm{~min}$. $\mathrm{Al}_{2} \mathrm{O}_{3}$ and $\mathrm{C}$ were the main phases at $1,550^{\circ} \mathrm{C}$ [Fig. 2(a)]. The formation of $\mathrm{B}_{4} \mathrm{C}$ by reaction (4) was reported to occur at $1,500^{\circ} \mathrm{C},{ }^{21}$ )

$$
2 \mathrm{~B}_{2} \mathrm{O}_{3(1, \mathrm{~g})}+7 \mathrm{C}_{(\mathrm{s})} \rightarrow \mathrm{B}_{4} \mathrm{C}_{(\mathrm{s})}+6 \mathrm{CO}_{(\mathrm{g})} .
$$

However, $\mathrm{B}_{4} \mathrm{C}$ was not identified by XRD.

The formation of $\mathrm{Al}_{4} \mathrm{C}_{3}$ began to occur at $1,600^{\circ} \mathrm{C}$ [Fig. 2(b)], indicating that the following reactions occurred at this temperature; ${ }^{23)}$

$$
\begin{aligned}
& \mathrm{Al}_{2} \mathrm{O}_{3(\mathrm{~s})}+3 \mathrm{C}_{(\mathrm{s})} \rightarrow 2 \mathrm{Al}_{(\mathrm{g})}+3 \mathrm{CO}_{(\mathrm{g})} \\
& 2 \mathrm{Al}_{2} \mathrm{O}_{3(\mathrm{~s})}+9 \mathrm{C}_{(\mathrm{s})} \rightarrow \mathrm{Al}_{4} \mathrm{C}_{3(\mathrm{~s})}+6 \mathrm{CO}_{(\mathrm{g})} \\
& 2 \mathrm{Al}_{2} \mathrm{O}_{(\mathrm{g})}+5 \mathrm{C}_{(\mathrm{s})} \rightarrow \mathrm{Al}_{4} \mathrm{C}_{3(\mathrm{~s})}+2 \mathrm{CO}_{(\mathrm{g})} \\
& 4 \mathrm{Al}_{(\mathrm{g})}+3 \mathrm{C}_{(\mathrm{s})} \rightarrow \mathrm{Al}_{4} \mathrm{C}_{3(\mathrm{~s})} .
\end{aligned}
$$

The amount of $\mathrm{Al}_{4} \mathrm{C}_{3}$ was maximum at $1,650^{\circ} \mathrm{C}$ [Fig. 2(c)]. Also, $\mathrm{Al}_{3} \mathrm{BC}_{3}$ began to form at this temperature. $\mathrm{Al}_{2} \mathrm{O}_{3}$ and $\mathrm{Al}_{4} \mathrm{C}_{3}$ were completely consumed and mono-phase $\mathrm{Al}_{3} \mathrm{BC}_{3}$ was attained at $1,800^{\circ} \mathrm{C}$.

TGA and XRD data indicated that the difference between the theoretical and experimentally determined optimum mass ratio of $\left[\mathrm{Al}(\mathrm{OH})_{3}+\mathrm{B}_{2} \mathrm{O}_{3}\right] / \mathrm{C}(3.73$ vs. 8.4) was attributed to the loss of the aluminum-based gases and $\mathrm{B}_{2} \mathrm{O}_{3}$ below $1,600^{\circ} \mathrm{C}$ because the gases did not actively form solid compounds at this temperature.

Figure 3 summarized the schematic of synthesis mechanisms. Below $1,050^{\circ} \mathrm{C}, \mathrm{Al}_{2} \mathrm{O}_{3}$ particles were covered with carbon which was derived from phenolic resin while $\mathrm{B}_{2} \mathrm{O}_{3}$ melted and distributed between the particles. Excess carbon formed agglom- 
erated particles [Fig. 3(a)]. The vaporization of $\mathrm{B}_{2} \mathrm{O}_{3}$ occurred above $1,050^{\circ} \mathrm{C}$.

$\mathrm{Al}_{2} \mathrm{O}$ gas was formed by reaction (3) above $1,500^{\circ} \mathrm{C} \cdot \mathrm{Al}_{2} \mathrm{O}$ and $\mathrm{B}_{2} \mathrm{O}_{3}$ were mostly vaporized without forming $\mathrm{Al}_{4} \mathrm{C}_{3}$ and $\mathrm{B}_{4} \mathrm{C}$ below $1,600^{\circ} \mathrm{C}$ [Figs. 2(b) and $3(\mathrm{~b})$ ]. At and above $1,600^{\circ} \mathrm{C}$, $\mathrm{Al}_{2} \mathrm{O}$ and $\mathrm{Al}$ gases, which were formed by reactions (3) and (5), reacted with carbon to form $\mathrm{Al}_{4} \mathrm{C}_{3}$ on the surface of carbon particles by reactions (7) and (8) [Fig. 3(c)].

Two types of diffusion can occur through $\mathrm{Al}_{4} \mathrm{C}_{3}$ layer in order to continue the reduction reactions; the inward diffusion of $\mathrm{Al}$ and $\mathrm{B}$ sources or outward diffusion of C. Among them, the diffusion of aluminum sources through the carbide layer was reported to be the dominant synthesis mechanism of $\mathrm{Al}_{4} \mathrm{C}_{3} .{ }^{23}$ ) The effective diffusivities of the components through $\mathrm{Al}_{4} \mathrm{C}_{3}$ were reported to be 0.82 and $1.31 \mathrm{~cm}^{2} / \mathrm{s}$, respectively. However, over $90 \%$ of the carbide was reported to be formed by $\mathrm{Al}_{2} \mathrm{O}$ and only $10 \%$ by $\mathrm{Al}$ because the vapor pressure of $\mathrm{Al}_{2} \mathrm{O}$ is much higher than that of $\mathrm{Al}^{23)}$

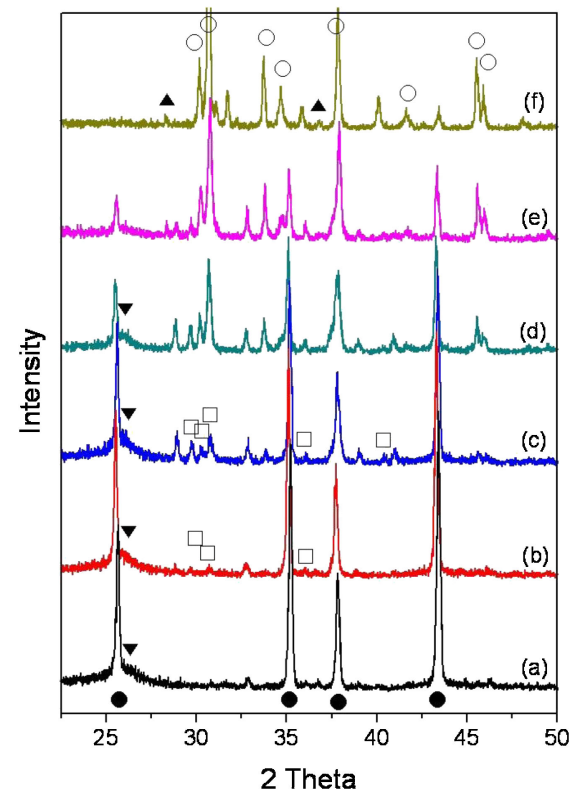

Fig. 2. XRD data of the powder mixtures after the calcinations of the $\mathrm{ABC} 3$ composition at (a) $1,550^{\circ} \mathrm{C}$, (b) $1,600^{\circ} \mathrm{C}$, (c) $1,650^{\circ} \mathrm{C}$, (d) $1,700^{\circ} \mathrm{C}$, (e) $1,750^{\circ} \mathrm{C}$ and (f) $1,800^{\circ} \mathrm{C}$ for $30 \mathrm{~min}$ in $\operatorname{Ar}\left(\bullet: \mathrm{Al}_{2} \mathrm{O}_{3}, \square: \mathrm{Al}_{4} \mathrm{C}_{3}\right.$, $\boldsymbol{\nabla}$ : carbon, $\bigcirc: \mathrm{Al}_{3} \mathrm{BC}_{3}, \boldsymbol{\Lambda}$ : unidentified peaks).
At $1,650^{\circ} \mathrm{C}$, boron source diffused into $\mathrm{Al}_{4} \mathrm{C}_{3}$ and formed $\mathrm{Al}_{3} \mathrm{BC}_{3}$ at the boundary between $\mathrm{Al}_{4} \mathrm{C}_{3}$ and $\mathrm{C}$ [Figs. 2(c) and $3(\mathrm{~d})$ ];

$$
3 \mathrm{Al}_{4} \mathrm{C}_{3(\mathrm{~s})}+9 \mathrm{C}_{(\mathrm{s})}+2 \mathrm{~B}_{2} \mathrm{O}_{3(\mathrm{~g})} \rightarrow 4 \mathrm{Al}_{3} \mathrm{BC}_{3(\mathrm{~s})}+6 \mathrm{CO}_{(\mathrm{g})} .
$$

Reaction (9) mainly occurred at the initial stage of synthesis because the synthesized $\mathrm{Al}_{3} \mathrm{BC}_{3}$ prevented the contact between $\mathrm{Al}_{4} \mathrm{C}_{3}$ and $\mathrm{C}$.

The formation of $\mathrm{Al}_{3} \mathrm{BC}_{3}$ continued mostly by the diffusion of $\mathrm{Al}$ and $\mathrm{B}$ sources through $\mathrm{Al}_{4} \mathrm{C}_{3}$ and $\mathrm{Al}_{3} \mathrm{BC}_{3}$ to react with carbon;

$$
\begin{aligned}
& 3 \mathrm{Al}_{2} \mathrm{O}_{(\mathrm{g})}+\mathrm{B}_{2} \mathrm{O}_{3(\mathrm{~g})}+12 \mathrm{C}_{(\mathrm{s})} \rightarrow 2 \mathrm{Al}_{3} \mathrm{BC}_{3(\mathrm{~s})}+6 \mathrm{CO}_{(\mathrm{g})}, \\
& 6 \mathrm{Al}_{(\mathrm{g})}+\mathrm{B}_{2} \mathrm{O}_{3(\mathrm{~g})}+9 \mathrm{C}_{(\mathrm{s})} \rightarrow 2 \mathrm{Al}_{3} \mathrm{BC}_{3(\mathrm{~s})}+3 \mathrm{CO}_{(\mathrm{g})} .
\end{aligned}
$$

Among the two reactions, reaction (10) is believed to be the major synthesis mechanism of $\mathrm{Al}_{3} \mathrm{BC}_{3}$ due to the high vapor pressure of $\mathrm{Al}_{2} \mathrm{O}$ compared to that of $\mathrm{Al}$.

When using $\mathrm{Al}, \mathrm{B}_{4} \mathrm{C}$ and $\mathrm{C}$ as source materials, the synthesis of $\mathrm{Al}_{3} \mathrm{BC}_{3}$ was reported to be dominated by solid-solid or liquidsolid reactions. ${ }^{14), 15)}$ However, most probably the major synthesis mechanism of $\mathrm{Al}_{3} \mathrm{BC}_{3}$ during carbo-thermal reaction is gas-solid reactions by reactions (9)-(11).

Figure 4 shows the morphology of synthesized $\mathrm{Al}_{3} \mathrm{BC}_{3}$. The particles synthesized by carbo-thermal reduction had large deviation in size [1-20 $\mu \mathrm{m}$, Fig. 4(a)]. The average particle size of $\mathrm{Al}_{3} \mathrm{BC}_{3}$ synthesized using $\mathrm{Al}-\mathrm{B}_{4} \mathrm{C}-\mathrm{C}$ at $1,800^{\circ} \mathrm{C}$ was $14.1 \mu \mathrm{m}$. The resultant particles had irregular morphology [Fig. 4(b)]. In contrast, the shape of terraces which were formed on the $\mathrm{Al}_{3} \mathrm{BC}_{3}$ powder synthesized through carbo-thermal reduction revealed the hexagonal nature of the compound [P6 $m c$, Fig. 4(c)]. Ceramic powders which were synthesized through gas reactions or dissolution-reprecipitation within liquid reveal their crystallographic character. ${ }^{21)}$ The formation of terraces shown in Fig. 4(c) indicated that $\mathrm{Al}_{3} \mathrm{BC}_{3}$ particulates grew partly by the reactions of gas phases with carbon at the surface of $\mathrm{Al}_{3} \mathrm{BC}_{3}$ [Fig. 3(e)].

The growth of terrace by gas reactions is mainly controlled by crystal structure, temperature, and the degree of supersaturation. ${ }^{25)}$ The nucleation and growth of crystals from vapor phases depend mainly on the supersaturation ratio between actual and equilibrium pressures. ${ }^{26)}$ When the degree of supersaturation increases, kink sites freely nucleate and grow on low energy planes and the growth on high energy plane is restrained. At an opposite condition, high energy planes grow out and crystal habits tend to develop. ${ }^{27)}$

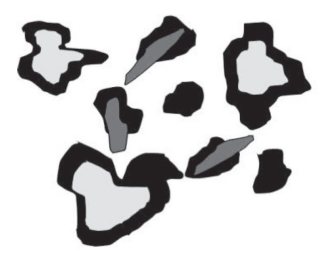

(a)

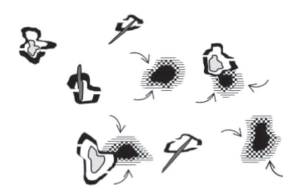

(d)

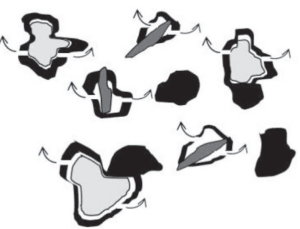

(b)

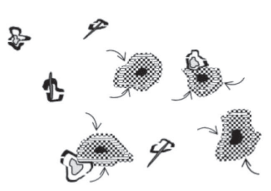

(e)

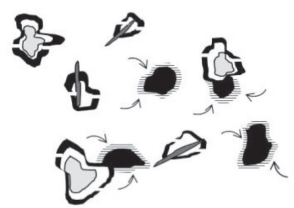

(c)

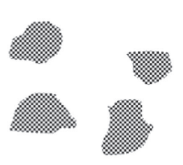

(f)

Fig. 3. Synthesis mechanisms of $\mathrm{Al}_{3} \mathrm{BC}_{3}$ by carbo-thermal reduction at various temperature. (a) below $1,050^{\circ} \mathrm{C}$, (b) 1,500 $1,600^{\circ} \mathrm{C}$, (c) $1,600-1,650^{\circ} \mathrm{C}$, (d), (e) above $1,650^{\circ} \mathrm{C}$ and (f) $1,800^{\circ} \mathrm{C}$. ( : $\mathrm{Al}_{2} \mathrm{O}_{3}$, ㅁ: $\mathrm{B}_{2} \mathrm{O}_{3}, \square: \mathrm{C}$, 目: $\mathrm{Al}_{4} \mathrm{C}_{3}, \mathrm{~B}^{\circ} \mathrm{Al}_{3} \mathrm{BC}_{3}$ ) 


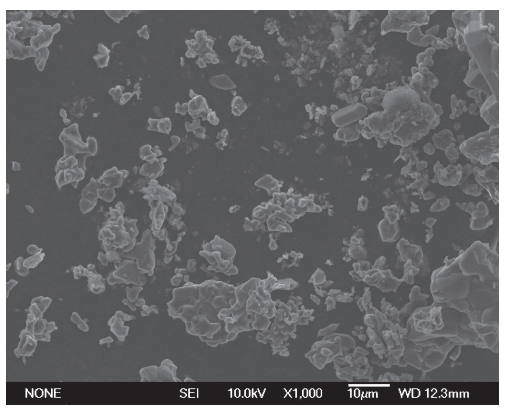

(a)

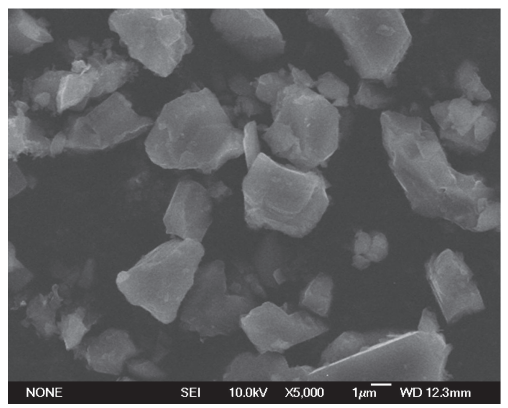

(b)

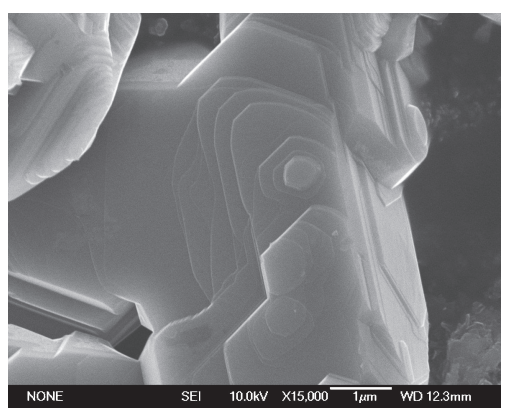

(c)

Fig. 4. Morphology of synthesized $\mathrm{Al}_{3} \mathrm{BC}_{3}$ powder after calcination at $1,800^{\circ} \mathrm{C}$ for $1 \mathrm{~h}$ using (a) $\mathrm{Al}(\mathrm{OH})_{3}-\mathrm{B}_{2} \mathrm{O}_{3}-\mathrm{C}$, (b) $\mathrm{Al}-\mathrm{B}_{4} \mathrm{C}-\mathrm{C}$ and (c) magnified view of Fig. 4(a).

The formation of hexagonal terraces shown in Fig. 4(c) indicated a two-dimensional (2D) nucleation-growth of both high and low energy planes. The crystallographic character is revealed when the growth rate of low energy plane is controlled. ${ }^{28)}$

During the synthesis of $\mathrm{Al}_{3} \mathrm{BC}_{3}$, the partial pressure of gases generated by, e.g., reactions (3), (5) was quite high due to the reactions between the oxides and carbon, which caused the supersaturation of the reactants for reactions (10) and (11) at the particle surface. Growth occurred both at the low and high energy planes of $\mathrm{Al}_{3} \mathrm{BC}_{3}$. Therefore, the synthesized $\mathrm{Al}_{3} \mathrm{BC}_{3}$ powder had a rather irregular-shape although hexagonal terraces were formed on the surfaces [Fig. 3(c)].

The synthesis time to produce $\mathrm{X}$-ray pure $\mathrm{Al}_{3} \mathrm{BC}_{3}$ decreased with increasing synthesis temperature; i.e., $4 \mathrm{~h}$ at $1,725^{\circ} \mathrm{C}, 2 \mathrm{~h}$ at $1,750^{\circ} \mathrm{C}$ and $1 \mathrm{~h}$ at $1,800^{\circ} \mathrm{C}$.

\subsection{Properties of synthesized $\mathrm{Al}_{3} \mathrm{BC}_{3}$}

Figure 5 shows the morphology of the as-synthesized powder compact. A black-colored layer formed at the top of the specimen. $\mathrm{Al}_{3} \mathrm{BC}_{3}$ powder which formed beneath the black layer

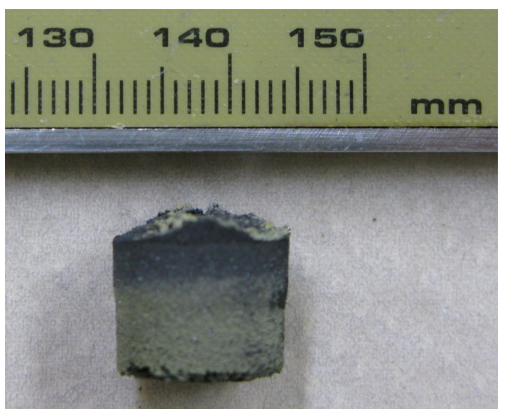

Fig. 5. Morphology of the specimen after calcination at $1,800^{\circ} \mathrm{C}$ for $1 \mathrm{~h}$.

Table 2. Chemical composition of the synthesized powder (wt \%)

\begin{tabular}{lllll}
\hline & Al & B & C & O \\
\hline Stoichiometry & 63.3 & 8.46 & 28.2 & \\
Green area & 59.6 & 8.2 & 30.9 & 1.9 \\
Black area & 34.3 & 4.4 & 33.3 & 24 \\
\hline
\end{tabular}

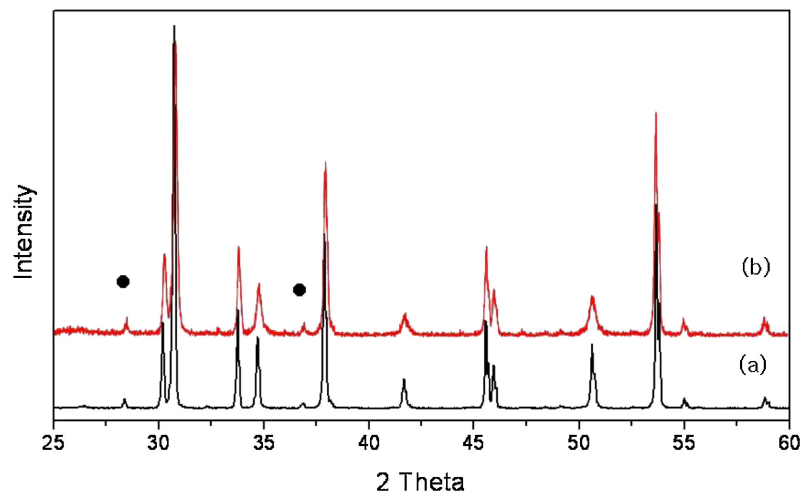

Fig. 6. XRD data of the synthesized $\mathrm{Al}_{3} \mathrm{BC}_{3}$ powders after calcination using (a) $\mathrm{Al}-\mathrm{B}_{4} \mathrm{C}-\mathrm{C}$ mixture at $1,800^{\circ} \mathrm{C}$ for $2 \mathrm{~h}$ in $\mathrm{Ar}$ and (b) $\mathrm{Al}(\mathrm{OH})_{3}-$ $\mathrm{B}_{2} \mathrm{O}_{3}-\mathrm{C}$ mixture at $1,725^{\circ} \mathrm{C}$ for $4 \mathrm{~h}$ in Ar. (O) unidentified peaks, others: $\left.\mathrm{Al}_{3} \mathrm{BC}_{3}\right)$

had dark green color. Table 2 summarized the weight ratio of the constituents after calcination at $1,800^{\circ} \mathrm{C}$ for $1 \mathrm{~h}$. The high oxygen content of the black-colored layer indicated the incomplete reaction at the top area of the powder compact. The strong decrease of $\mathrm{Al}$ and $\mathrm{B}$ contents within the black layer was caused by the vaporization of $\mathrm{Al}_{2} \mathrm{O}, \mathrm{Al}$ and $\mathrm{B}_{2} \mathrm{O}_{3}$ gases below $1,600^{\circ} \mathrm{C}$. The black surface layer suppressed the vaporization inside the powder compact, thus helped the formation of $\mathrm{Al}_{3} \mathrm{BC}_{3}$.

The synthesized $\mathrm{Al}_{3} \mathrm{BC}_{3}$ powder contained $1.9 \mathrm{wt} \%$ of oxygen. Part of the oxygen was believed to be originated from the oxides or oxihydrates which were formed on the surface of $\mathrm{Al}_{3} \mathrm{BC}_{3}$ by the reaction with humidity during handling and storage.

Figure 6 shows the $\mathrm{X}$-ray data of $\mathrm{Al}_{3} \mathrm{BC}_{3}$ synthesized using $\mathrm{Al}(\mathrm{OH})_{3}-\mathrm{B}_{2} \mathrm{O}_{3}-\mathrm{C}$ and $\mathrm{Al}-\mathrm{B}_{4} \mathrm{C}-\mathrm{C}$ raw powder mixtures. Al$\mathrm{B}_{4} \mathrm{C}-\mathrm{C}$ powder mixture has been commonly used to synthesize $\mathrm{Al}_{3} \mathrm{BC}_{3}$ through the direct reactions between molten $\mathrm{Al}, \mathrm{B}_{4} \mathrm{C}$ and C. ${ }^{15)}$ In both cases, nearly X-ray pure $\mathrm{Al}_{3} \mathrm{BC}_{3}$ were obtained. Interestingly, small unidentified peaks were detected at 28.5 and $36.9^{\circ}$ regardless of the types of starting materials and synthesis mechanism. The peak broadening of $\mathrm{Al}_{3} \mathrm{BC}_{3}$ synthesized through carbo-thermal reduction was larger than that made using $\mathrm{Al}-$ $\mathrm{B}_{4} \mathrm{C}-\mathrm{C}$ powder, indicating that the former one had a smaller crystallite size. ${ }^{29)}$ 


\section{Conclusions}

Mono-phase $\mathrm{Al}_{3} \mathrm{BC}_{3}$ was successfully synthesized using a mixture of $\mathrm{Al}(\mathrm{OH})_{3}, \mathrm{~B}_{2} \mathrm{O}_{3}$, and phenolic resin through carbothermal reduction process. The loss of the source materials by vaporization occurred below $1,600^{\circ} \mathrm{C}$. At $1,600^{\circ} \mathrm{C}, \mathrm{Al}_{2} \mathrm{O}$ gas reacted with carbon to form $\mathrm{Al}_{4} \mathrm{C}_{3}$ on the carbon particles. $\mathrm{Al}_{3} \mathrm{BC}_{3}$ was formed at $1,650^{\circ} \mathrm{C}$ by the diffusion of $\mathrm{Al}, \mathrm{Al}_{2} \mathrm{O}$ and $\mathrm{B}_{2} \mathrm{O}_{3}$ gases through $\mathrm{Al}_{4} \mathrm{C}_{3}$ layer and subsequent reaction with carbon. Hexagonal terrace at the surface of synthesized powder indicated that the gases also reacted at the particle surface with carbon. The optimum mass ratio for obtaining nearly X-ray pure compound was $\mathrm{Al}(\mathrm{OH})_{3}: \mathrm{B}_{2} \mathrm{O}_{3}:$ carbon $=0.7: 1.4: 0.25$. Excess $\mathrm{Al}(\mathrm{OH})_{3}$ and $\mathrm{B}_{2} \mathrm{O}_{3}$ were required due to the loss below $1,600^{\circ} \mathrm{C}$. Gas-solid reaction between $\mathrm{Al}_{2} \mathrm{O}, \mathrm{B}_{2} \mathrm{O}_{3}$ gases and $\mathrm{C}$ was the major synthesis mechanism of the ternary powder.

\section{References}

1) L. S. Sigl, J. Eur. Ceram. Soc., 23, 1115-1122 (2003).

2) T. Zhang, Z. Zhang, J. Zhang, D. Jiang and Q. Lin, Mater. Sci. Eng., A, 443, 257-261 (2007).

3) W. Si, T. J. Graule, F. H. Baader and L. J. Gauckler, J. Am. Ceram. Soc., 82, 1129-1136 (1999).

4) I. Ganesh, D. C. Jana, S. Shaik and N. Thiyagarajan, J. Am. Ceram. Soc., 89, 3056-3064 (2006).

5) S. H. Lee, Y. Sakka, H. Tanaka and Y. Kagawa, J. Am. Ceram. Soc., 92, 2888-2893 (2009).

6) S. H. Lee, H. Tanaka and Y. Kagawa, J. Eur. Ceram. Soc., 29, 2087-2095 (2009).

7) S. H. Lee, B. N. Kim and H. Tanaka, J. Mater. Res., 25, 471475 (2010)

8) H. Hillebrecht and F. D. Meyer, Angew. Chem. Int. Et. Engl., 35, 2499-2500 (1996).

9) C. Jardin, H. Hillebrecht, J. Bauer, J. F. Halet, J. Y. Saillard and R. Gautier, J. Solid State Chem., 176, 609-614 (2003).

10) V. L. Solozhenko, F. D. Meyer and H. Hillebrecht, J. Solid
State Chem., 154, 254-256 (2000).

11) J. Wang, Y. Zhou, T. Liao and Z. Lin, Appl. Phys. Lett., 89, 021917 (2006).

12) T. Wang and A. Yamaguchi, J. Ceram. Soc. Japan, 108, 375380 (2000).

13) Z. Inoue, H. Tanaka and Y. Inomata, J. Mater. Sci., 15, 30363040 (1980).

14) F. Li, Y. Zhou, L. He, B. Liu and J. Wang, J. Am. Ceram. Soc., 91, 2343-2348 (2008).

15) S. H. Lee, J. S. Lee, H. Tanaka and S. C. Choi, J. Am. Ceram. Soc., 92, 2831-2837 (2009).

16) S. H. Lee, H. D. Kim, S. C. Choi, T. Nishimura, J. S. Lee and H. Tanaka, J. Eur. Ceram. Soc., 30, 1015-1020 (2010).

17) N. A. Hassine, J. G. P. Binner and T. E. Cross, Inter. J. Hazard. Mater., 13, 353-358 (1995).

18) J. S. Lee, S. H. Lee, T. Nishimura and H. Tanaka, J. Am. Ceram. Soc., 92, 1030-1035 (2009).

19) J. S. Lee, S. H. Lee, T. Nishimura and H. Tanaka, J. Ceram. Soc. Japan, 116, 717-721 (2008).

20) S. Onaka, H. Miura and M. Kato, J. Mater. Sci. Lett., 19, 279281 (2000).

21) C. H. Jung, M. J. Lee and C. J. Kim, Mater. Lett., 58, 609-614 (2004).

22) P. Lefort, D. Tetard and P. Tristant, J. Eur. Ceram. Soc., 12, 123-129 (1993).

23) R. J. Fruehan, Y. Li and G. Carkin, Metall. Mater. Trans., B, 35, 617-623 (2004).

24) J. Zhao, W. Lin, A. Yamaguchi, J. Ommyoji and J. Sun, J. Ceram. Soc. Japan, 115, 654-660 (2007).

25) H. Wang, D. O. Northwood, J. Han and S. Du, J. Am. Ceram. Soc., 89, 501-508 (2006).

26) W. K. Burton, N. Cabrera and F. C. Frank, Philos. Trans. R. Soc. Lond. A, 243, 299-358 (1951).

27) B. Lewis, J. Cryst. Growth, 21, 29-39 (1974).

28) R. Fu, H. Zhou, L. Chen and Y. Wu, Mater. Sci. Eng., A, 266, 44-51 (1999).

29) A. Patterson, Phys. Rev., 56, 978-982 (1939). 